\title{
A Patient's Tale of Incarceration in a Victorian Lunatic Asylum
}

\author{
CAROL BERKENCOTTER* \\ University of Minnesota
}

Received: 15 February 2010 / Accepted: 26 March 2010

\begin{abstract}
Using the archival admissions records and the case history of a patient at a British asylum in the 1870s, the author compares two genres. The first of these is two medical certificates written and signed by two physicians attesting that the patient was of unsound mind and needed to be confined and treated. The second genre is the patient's oral testimony to Parliament's Select Committee on Lunacy Laws (1877), a narrative he delivered the year following his release from the asylum. Both genres are legal texts; however, it is the patient's narrative of personal experience, as transcribed in the committee report, that allows the reader a glimpse of the misery imposed by confinement in a "lunatic" asylum. The two medical certificates have considerably more illocutionary force, however; as speech acts they most often resulted in confinement until the patient was determined to have recovered, was transferred to another asylum, or died.
\end{abstract}

\section{KEYWORDS:}

Genre, narratives of personal experience, case history, medical certificates, Ticehurst House Asylum, mental patient, insanity.

\section{RESUMEN}

Utilizando el archivo de registros de admisión y la historia clínica de un paciente en un psiquiátrico británico de los años 1870, se comparan dos géneros. El primero consiste en dos certificados médicos escritos y firmados por dos psiquiatras certificando que el paciente estaba mentalmente incapacitado y necesitaba confinación y tratamiento. El segundo género se trata del testimonio oral del paciente ante el Parliament's Select Committee on Lunacy Laws (1877), pronunciado al año siguiente de su alta. Ambos géneros son textos legales, sin embargo, es la narración de la experiencia personal del paciente, transcrita en el informe del comité, lo que permite obtener una visión de las miserias impuestas por el encierro en un sanatorio de lunáticos. Los certificados médicos tienen una fuerza ilocutiva considerablemente mayor, pero como actos del habla resultaban en la reclusión del paciente hasta que se determinaba su recuperación, su traslado a otro sanatorio o fallecía.

\section{PALABRAS CLAVE:}

Género, narración de experiencias personales, historia clínica, certificado médico, Ticehurst House Asylum, pacientes mentales, demencia.

*Address for correspondence: Carol Berkenkotter. University of Minnesota, Twin Cities. 640, 13 ${ }^{\text {th }}$ Ave. NW, New Brighton, MN 55112, USA. Tel: 651631 1141; Fax: 612624 3617; E-mail: cberken@umn.edu 


\section{INTRODUCTION}

Narrative inquiry does not belong to any one discipline, but rather over the last three decades has become an interdisciplinary nexus of different methods by which humanistic scholars and empirical researchers analyze a wide range of oral and written texts. These include novels, film, short stories, movies, poetic and prose epics, psychotherapy interviews, oral memoirs, chronicles, histories, comic strips and other visual media, such as graphic novels. This efflorescence of approaches to narrative from the social and human sciences has reinvigorated interest in how narrative knowledge is constituted in "everyday speech and ordinary discourse” (White, 1987: 26). Although different interpretations of everyday speech and ordinary discourse cover a broad canvas, we can most likely include within its frame the following exemplars: discourse analyses of narratives in social interactions by anthropological and applied linguists (Capps \& Ochs, 1995; Goodwin, 1984; Ochs \& Capps, 2001; Ochs, Smith, \& Taylor, 1989), and genre analyses of ordinary discourse, in the form of narratives in professional and medical settings (Berkenkotter \& Ravotas, 1997; Coupland \& Coupland, 1998; Fakhri 1998; Mishler, 1997; Ravotas \& Berkenkotter, 1998).

Yet it is difficult to find non-literary historical narratives of personal experience. Unlike the published patient memoirs (Merivale, 1879; Perceval, 1840), narratives, and especially the narratives of patients diagnosed as being insane (as mental illness was called in the nineteenth century), are most often buried in the rare collections archives of libraries such as the Wellcome Library for the History of Medicine in England. It is even more unusual to find transcribed oral narratives of personal experiences, which is why these patients' stories are extremely hard to find.

The present study is an attempt to fill this gap by comparing two accounts of the mental status of a patient, Walter Marshall, who was admitted to Ticehurst House Asylum in Surrey, England in May, 1876, and was discharged four months later in September, 1876. The first account is constituted by two medical certificates (appearing in Marshall's Admissions Record) that had been filled out and signed by physicians, each of whom attested that Marshall was of unsound mind, and therefore required confinement in an asylum where he would receive care and treatment. The second account is a written transcript of Marshall's (oral) testimony to members of Parliament's Select Committee at a hearing to determine the incidence possible abuses of patients and, in particular, the wrongful confinement of an individual.

To describe the history of Walter Marshall (a wealthy patient who protested the grounds for his confinement at Ticehurst Asylum between May and September, 1876), I integrate concepts from genre analysis and speech act theory, concepts that shed light on the contradictions between two genres, one institutional, the other, an oral narrative of personal experience. The first of these, the Medical Certificates (which appear in Marshall's Admissions Record, May, 1876) are legal as well as medical documents that must be filled 
out and signed by two physicians -although the physicians do not have to be specialists in mental illness- in fact most were not. Medical certificates that are filled out correctly and in the appropriate time period (two days to one week) before confinement were legally necessary for the confinement to be legal. They depict the patient in such a way that is considerably at odds with Walter Marshall's testimony twelve months later before Parliament's 1877 Select Committee hearing on possible violations of England's Lunacy Laws (1844). Marshall was one of several former patients who testified regarding possible abuses of the law with regard to wrongful confinement.

The medical certificates are a genre that functions rhetorically as a performative, or speech act, in this case, what Searle (1979) described as a declarative, i.e., that "this man is of unsound mind, and needs to be confined -and treated- in an asylum.” The uptake (Austin, 1962; Freadman, 2004) of this speech act is incarceration because the medical certificate is a legal document possessing a powerful illocutionary force (Austin, 1962; Searle, 1979). Marshall's testimony before the Select Committee -his narrative of the events leading to confinement- is also a genre; however, in speech act terminology it has little if any illocutionary force in the legal context in which it occurs. In contrast, Marshall's interlocutors (the physicians who asked the questions at the Select Committee hearing) possessed the institutional authority to change the law, had his narrative persuaded them that his right of habeas corpus had been violated. Because the 1877 Select Committee Hearings were transcribed, we have a written facsimile of Marshall's testimony. Before turning to the details of Marshall's case, and in the context of my use of narrative inquiry in this essay, I first present an overview of the growth over the last 25 years of research into narratives of personal experience.

\section{THE NARRATIVE TURN IN THE SOCIAL AND HUMAN SCIENCES ${ }^{1}$}

Since the mid 1980s, scholars outside the fields of literary criticism, but interested in narrative, have been publishing their research in journal articles, collections, and scholarly monographs. The field of narratology -first conceived among the structuralist narratologists such as Todorov (1990) and Barthes (1977)- morphed into an interdisciplinary nexus of scholars in a number of disciplines, and non-literary narrative studies began to appear in collections and journals such as The Journal of Narrative and Life History and Narrative inquiry. A number of factors seem to have converged to produce a climate of intellectual cross-pollination by the 1980s, although sociolinguists, such as Labov, had begun to study narrative in non-literary discourses and texts in the late 1960s and 1970s (Labov, 1972; Labov \& Waletzky, 1967; White, 1973).

In 1981, one of the first interdisciplinary collections, On Narrative (edited by W.T J. Mitchell), appeared featuring a group of well-known scholars and writers, including Derrida, White, Turner, and, as well, the novelist, Ursula K. Le Guin. The sequence of events leading 
to the publication of On Narrative began with a symposium Narrative: The Illusion of Sequence, held six years earlier at the University of Chicago in late 1975. As editor Mitchell proclaimed in his forward:

This collection provides an interdisciplinary compendium of some of the most important thinking on narrative [...] Reflecting the debates and collaboration of literary critics, philosophers, anthropologists, psychologists, art historians, and novelists, the collection is intended to carry thinking about the problem of narrative well beyond the province of the 'aesthetic'-that is, poetic, dramatic, or fictional narrative- and to explore the role of narrative in social and psychological formation (1981, vii.).

In many ways the Chicago conference and Mitchell's two special issues of the literary journal, Critical Inquiry, which followed a few years later, heralded the news that scholars in a number of disciplines (anthropology, sociolinguistics, psychology, history) had become interested to the concept of narrative (outside of literature) as an object of study.

On Narrative, a collection created from the essays in Critical Inquiry, was published in 1981. The book was a harbinger of a migration of scholars across disciplinary boundaries, and a turn toward narrative inquiry that enlisted the collaboration of researchers across the social and human sciences. During the 1980s, scholars representing disciplines as diverse as social psychology, sociolinguistics, history, counseling, psychiatry, and psychoanalysis began publishing essays on non-fiction narratives in journals and books. One such work was Hayden White's groundbreaking The Content of the Form: Narrative Discourse and Historical Representation (1987), which made the case for historiography, the study of the history writing as one of forms of representation of historical narratives and the relationship of form to what White calls the plausible story: "For the narrative historian, the historical method consists in investigating documents in order to determine what is the truest or most plausible story that can be told about the events of which they are evidence” (27). However, according to White, the reader should not accept the windowpane view of the relationship between representation and historical reality. In fact the relationship is at least once removed: As White puts the matter, "The story told in the narrative is a mimesis of the story lived in some region of historical reality, and insofar as it is an accurate imitation, it is to be considered a truthful account thereof” (27). White's view of the form of historical discourse as being a simulacrum of the structure and processes of real events made the practice of critical reflexivity central to the interpretive human sciences. More important, his interrogation of the historical genres in his discipline was paralleled by an interpretive turn in other social sciences, such as anthropology as the disciplinary genres (e.g., ethnography) were held up to the harsh light of reflexivity (see for example, Clifford \& Marcus, 1986).

At about this time -the mid 1980s- there were also interdisciplinary discussions of narrative case histories in medicine that appeared in special issues of Perspectives in Medicine and Biology and Literature and Medicine. For example, in Literature and Medicine (vol. 5, 1986), there appeared a lively exchange between physicians and humanists over the formal 
features of the clinical case history. This colloquy began with David Barnard's detailed case history of a man suffering from Amyotrophic Lateral Sclerosis (ALS), a devastating and fatal neurological disorder, and responses to Barnard's narrative by two humanists: a literary critic, Eric Rabkin, and a philosopher and ethicist, David Smith. Rabkin took Barnard to task for serving up a biased account, despite the objective register in which the narrative was putatively an account of real events. Using the techniques of a deconstructive reading, Rabkin examined Barnard's case history as a simulacrum (i.e., a constructed account) of actual historical events and process, in which the participant-observer, Barnard, placed the physician's point of view in the centre of the story, while marginalizing the perspective of the patient -Mr. Baker- whose views were reduced to quotations or reported speech in small print. In contrast to Rabkin's critical reading of Barnard's case history, Smith chose to explicate the core moral conundrum that the narrative raised: how to depict through narrative techniques the questions of meaning for the patient and his wife, when faced with the fate of Job -that is, dying slowly of ALS's devastating physiological deterioration. This was the moral dilemma, suggested Smith, that made Barnard's narrative compelling. What, -asked Smith-, is the narrator's responsibility for foregrounding the existential issues surrounding this patient's end of life treatment?

The essays by Barnard, Rabkin, and Smith were prefaced by a brief essay by the editor, Joan Trautmann Banks, who described why she had chosen to feature these three essays under the heading: A Controversy about Clinical Form. Three other essays on the importance of narrative in medicine were included in this special issue on the clinical case history narrative form. They were titled A.R. Luria and the Art of Clinical Biography, by Anne Hunsacker Hawkins; Clinical Tales, by Oliver Sacks; and To Render the Lives of Patients, by Rita Charon. All three of these authors were well known to the readers of Literature and Medicine, Hawkins and Sacks as narratologists (Sacks, as well, for his own contributions to the art of the clinical narrative), and Charon as a physician taking an unorthodox approach to training her medical residents to write case history narratives. (She required medical residents to read narratives by authors of nineteenth and twentieth century British and American fiction, in order to teach them narrative techniques).

By the 1990s, the time had become ripe for the appearance of a number of other publications and commentaries on the nature of narrative knowledge in the human and social sciences. And by 2000, the study of narrative discourse had become common for investigators in many different fields beyond the humanities.

\section{A TURN TO FROM INSTITUTIONAL CASE HISTORIES TO THE PATIENT'S NARRATIVE OF PERSONAL EXPERIENCE}

When I published the book, Patient Tales: Case Histories and the Uses of Narrative in Psychiatry (2008), little did I think that some reviewers would be puzzled -and even 
chagrined- at the lack of the patient's perspective in the 200 years of case histories that I covered in the book. One reviewer wrote: "To this end, the title was a bit misleading in that the book examines the case histories from the clinician's perspective. The patient's perspective, especially when mentioned in the clinician's notes, is acknowledged to provide interesting analysis and intriguing opportunity to see the power of narrative, but this is not the main subject of the book" (Routesong, 2010). Apparently this reviewer (who was not alone), thought that, Patient Tales, referred literally to tales by patients, rather than psychiatry's case histories as a genre. I was especially surprised when the reviewer from the journal, History of Psychiatry, objected on the same grounds to the title as misrepresenting the content of the book, and listed a number of historians who had studied diaries, memoirs, and letters written by insane patients in the eighteenth and nineteenth centuries in Britain and the United States.

As a response to the criticisms that Patient Tales ignored the actual patient's narrative of his or her experience, this essay reports on material that is part of a larger study of three patients at Ticehurst House Asylum in Surrey, England from the 1860s-1870s. Two of these patients testified in a public forum about their experience of confinement at Ticehurst; coincidentally, they happened to be residing at the asylum at the same time, although their periods of confinement overlapped. It should be noted that Ticehurst Asylum was a private mental hospital for wealthy, lunatic patients (as they were called throughout the nineteenth century and before), whose families could no longer care for them when their behaviors had become too disruptive for them to remain at home. Some of these patients entered private care in a household of a doctor; however, most often families chose to place their mentally ill relatives in a setting that would be closest to the social setting and amenities that they had enjoyed in homes of the affluent in Victorian England.

\section{THE CASE OF WALTER MARSHALL}

Walter Marshall's case is well documented in Ticehurst Asylum's admissions records and by Samuel Newington's case notes written during Marshall's confinement from May 13 to September 3, 1876, at which time he was transferred to single care with a Dr. Hall in Brighton and released a month later. In addition to Marshall's admissions records and his case notes, we also have his transcribed testimony from the 1877 Parliamentary Select Committee hearing, reported in the Report on Lunacy Law. It was at these hearings that Marshall presented his side of the story of his incarceration at Ticehurst. Marshall's testimony to the Select Committee presents a sharp contrast to the information in Ticehurst's admissions records. His narrative suggests that certifying a person as being of unsound mind could be a problem when his or her symptoms were misinterpreted. I will return to this issue later. 


\section{MARSHALL'S ADMISSION RECORDS: THE MEDICAL CERTIFICATES}

The two medical certificates that accompany the Order for the Reception of a Private Patient (made by Marshall's wife, Annie) admit of no doubt on either physician's part regarding the state of Marshall's mind. Medical certificate \#1, signed by Dr. David E. Seaton, attests that he examined Mr. Marshall on the $3^{\text {rd }}$ of May 1876 at his place of abode 23 Thurlow Square, and concludes that Marshall is "of unsound mind and a proper Person to be taken charge of and detained under Care and Treatment," and "that I have formed this opinion on the following grounds." 2

1. Facts indicating Insanity observed by myself: "He received me in a most excited manner and talked incessantly of the part he had played in the election for a member of Parliament to represent the county of Cumberland, and of his having bought four horses. That he intended to give himself two years to live \& that he in the meanwhile would act as he chose, that he would kill himself, and what, he asked, would that matter? Mr. Marshall's ordinary state is one of depression (chronic) of mind, gentle in manner, and reticent -he is now in an excited and extravagant frame of mind (italics added for emphasis).

2. Other facts (if any) indicating Insanity communicated to me by others: Mrs. Marshall has communicated to me that Mr. Marshall believes himself inspired and under this inspiration believes that whatever he does is right. Mrs. Marshall tells me also, that he proposes to lend five thousand pounds to a person whom he has seen only twice, and from whom he purchased one of the horses, and though one of his solicitors demurred [from] carrying out his instructions for this loan. Mr. Marshall persists in lending his money without taking any security. This fact he also communicated to me (AR 6328/16).

Examining these statements from a speech act perspective, Seaton's certificate appears to be complex illocutionary act sequence. The certificate combines commissives "I the undersigned, Dr. David E. Seaton, being a Bachelor of the University of London and Fellow of the Royal College of Physicians, and being in actual practice as a surgeon personally examined Walter James Marshall," with the declarative "and find him not to be of sound mind and a proper person to be taken charge of and detained under Care and Treatment." The next statement, "I have formed this opinion on the following grounds" foregrounds the series of assertives that follow.

The second medical certificate, which was written and signed by Dr. John James, is a mirror image of Dr. Seaton's certificate:

I, the undersigned John James, being a Bachelor of the University of London and Fellow of the Royal College of Physicians, and being in actual practice as a surgeon,

Personally examined Walter James Marshall, at... [gives Marshall's address] and find him to be a person of unsound mind and a proper Person to be taken charge of and detained under Care and Treatment. I have formed this opinion upon the following grounds; viz.:

1. Facts indicating insanity observed by myself: On introduction to him today, he did not desire another medical man after Dr. Seaton, then began to read aloud the Book of Common Prayer, an epistle and some collects; then said he was very clever and would go into Parliament, that he endured afflictions and insult unjustly inflicted because it was 
acceptable with God; his manner was excited, \& ideas rambling from point to point; these observations do not seem [...] but his friends [writing becomes illegible here].

2. Other facts (if any) indicating Insanity communicated to me by others: Mr. J. Myers, Mr Ernest Myers, Mr. Douglass, tell me that he is normally a quiet, retir[ing] man, gentle and polite, lately he has become violent in language, enters into pecuniary transactions with great rashness viz. Amongst others (are) and a first interview with a [word illegible] previously unknown to him, Mr. Marshall, suddenly agreed to give him five thousand pounds at 4 percent because the corn chandler whom he alleged [to be] a gentleman, and would at once go into Parliament with him."

Signed Name, John M James. M.B. London, FRCS, 11 Thurlor Square.

Dated this third Day of May, 1876 (AR 6328/16).

Drs. Seton's and Dr. James' medical certificates function to initiate an argumentation sequence, to borrow a concept from van Eemeren and Grootendorst (1984). This is to say that the medical certificates are "an illocutionary act of complex argumentation," (p.35), the outcome of which is persuading the audience, the Commissioners in Lunacy. And indeed, the Commissioners in Lunacy were persuaded, as was Samuel Newington, who posted the Notice of Admission of a Private Patient, within twenty-four hours after the medical certificates had been signed.

\section{WALTER MARSHALL'S TESTIMONY TO THE PARLIAMENT'S SELECT COMMITTEE ON LUNACY LAWS: AN ORAL NARRATIVE OF PERSONAL EXPERIENCE}

In addition to Marshall's admissions records and his case history from Ticehurst Asylum, I was able to obtain (again from a medical archive), Marshall's transcribed oral testimony from the 1877 Parliamentary Select Committee hearing, as reported in the Report on Lunacy Law (1877). It was at these hearings that Marshall presented his side of the story of his incarceration at Ticehurst. Drawing from primary and secondary sources, I have constructed a narrative context in which I frame Marshall's testimony, as well quoting extensively from that testimony.

Neither Marshall's wife, nor his friends had considered him to be insane, despite the fact that he had been depressed off and on for many years before he became a patient at Ticehurst in May 1876. ${ }^{3}$ Between episodes of mild to severe depression and alternating periods of nervous excitement, during which Marshall became extravagant in his speech, spent large sums of money, and backed business deals that his family believed to be illadvised, he was "in his normal condition, gentle, courteous, moderate in all ways and of sound and deliberate judgment, and most truly generous of mind” (AR6328/16). Marshall's lucid intervals thus gave his wife and friends reason to believe that his attacks of depression were a form of severe nervous attack. As Dr. Headland, Marshall's attending physician in 1859, told his father, "You must not treat this man as insane; it is nervous illness, and not insanity.” Yet, despite this assurance, by early 1876 Marshall's behavior had become 
increasingly aberrant. During the few weeks prior to Marshall's being certified, he had become very excited as he campaigned for the Liberals during the election season.

In order to present a clearer picture of how Walter Marshall came to be certified by two physicians in early May, 1876, the point needs to be made that Marshall's long suffering wife, Annie, after many years of being the supportive Victorian wife, finally one night was driven to leave the house to seek help for her husband in the form of confinement in an asylum. Marshall was becoming increasingly voluble, engaging in excessive spending, and - as wellhis sleeplessness (he woke regularly at $5 \mathrm{am}$ ) may have contributed to her decision. In any case, on May 2, 1876 Annie, filled out the petition, Order for the Reception of a Private Patient, the first in the series of illocutionary acts leading to Marshall's confinement at Dr. Blandford's Asylum, Munster House in Fulham, followed by his transfer on May 13 to Ticehurst Asylum, at his father-in-law’s request. A year after he had been confined, in June 1877, Marshall recounted at a hearing before the Parliament's Select Committee on Lunacy Law, what must have been a harrowing scene at his residence (as transcribed from Minutes of Evidence Taken Before the Select Committee on Lunacy Law: 419-429):

On the morning of May 3rd last year, two doctors came to my house without any warning... I was alone at breakfast; I saw [the first doctor] come up to the house; I went to the door to let him in. He came into the room where I had breakfast. He began to talk about the health of my wife and children. Then apropos of nothing at all he said, 'You are very excited' or, 'you have been behaving in a very excited manner, and you require medical care.' Then I told him that I had just returned from an election which was very exciting work, and if I required any medical treatment, I should ask for it; in fact I said to him, 'If you think I want any tonic, or anything of that sort, I will ask you to give me a prescription' [...].

He was not satisfied. He said 'Well but you are very excited and require medical care.' When I finished my breakfast I left the room to go to my study and he followed me. . . In my study I found a gentleman sitting on the sofa whom I had never seen before. Dr. Seton introduced this gentleman as his friend, Dr. James, and said 'I wish you to see Dr. James.' I objected: Of course, I said, I had no reason to consult Dr. James. However, he insisted; and knowing what I knew of him, I thought there was no harm, and I saw Dr. James also. They were there for some time; I began to see there was something wrong, and I saw what they might be coming for. Moreover, I heard in the house the voices of two men downstairs who had come to the house with them, who were keepers from Dr. Blandford's Asylum (Minutes of Evidence, p. 419).

Despite Marshall's protestations, he found himself being grabbed by the two keepers from Dr. Blandford's asylum and shoved into a four-wheeled cab, while the two physicians, Seton and James, drove away in a hansom cab. Marshall's realization of the dire change in his circumstances has been recorded in his testimony to the questions by one member of the Parliament's Select Committee, who inquired, "What happened when you arrived at Munster House?” Marshall replied:

I went into a room and saw the medical man in charge there. Of course by that time I was very much distressed, and perhaps rather excited; but I was in command of my senses, 
and I appealed to him very strongly... I stayed [in the public room] till Dr. Blandford came in the afternoon... I appealed to him most strongly. I said, 'For God's sake take me out of this place.' He had seen me before. He said 'You have been committed to me by the certificates of those two doctors, and I am going to take care of you" (Minutes of Evidence, p 420).

Recognizing the seriousness of his predicament, that day Marshall telegraphed his lawyer and wrote to his wife. He was allowed to meet with his lawyer two days later (May 3, 1876), and during the following two days (May 4 and 5), he wrote to the Commissioners in Lunacy objecting to his confinement. The consequence was that Marshall was visited by two Commissioners in Lunacy, who came to Munster Asylum on Tuesday May 9, 1876. The two commissioners spent part of the morning seeing the patients generally, after which they conducted an interview with Marshall in a [separate] room:

I, as far as I can remember, told them the facts of the case; but I also made very strong mention of what I had witnessed in the asylum. I had seen, as I supposed, an old man treated very cruelly. I simply wished to say that I had been six days in the place... and if it [my confinement] had not been a mistake, I should be better, in fact. I mean to say that during those six days there was a greater strain on my powers of every sort, than ever I wish to go through again, and very likely I did show some traces of suffering and excitement (Minutes of Evidence, p. 420).

Marshall's complaints of abuse did convince the Commissioners in Lunacy to act, although not as he expected. He was transferred from Munster House to Ticehurst Asylum on May $13^{\text {th }}$. In his testimony to the Select Committee's question "What was the reason, if there was any reason assigned for the transfer," Marshall replied, "I think it was my wish mainly; I expressed a very strong wish to Leave Munster House, and the Commissioners said, "Very well, you can go to Ticehurst” (p. 421).

\section{THE IRREVOCABILITY OF THE MEDICAL CERTIFICATES}

The transcript of the Minutes of Evidence of the 1877 Select Committee's hearing on Marshall's complaint of wrongful confinement, reveals the nature of the "double bind" in which this patient found himself, a double bind not dissimilar to that of the pseudo-patients from the essay by David L. Rosenhan, Of Being Sane in Insane Places (1973). In Rosenhan's frequently cited study, he and his graduate students presented themselves at various psychiatric hospitals and hospital wings, displaying the symptoms of schizophrenia. After having been admitted, they had been instructed to behave in a normal way. Despite the changes in behaviors and language of these pseudo-patients, the staff on psychiatric wards interpreted their actions and language in the context of the diagnostic label to which they had been assigned. Despite the evidence of sanity that Rosenhan and his students presented to their keepers, they had great difficulty being discharged. In the case of Walter Marshall, a similar set of circumstances appears to have resulted from the irrevocability of the 
information in the Medical Certificates, documents composed by Drs. Seaton and James after each had interviewed Marshall. In turn, Seaton and James, who had read the information in Mrs. Marshall's initial Order for the Reception of a Private Patient, appear to have drawn many of their observations and conclusions from the information provided by Annie Marshall and appearing in the Order.

Similar to the plight in which Rosenhan and his graduate students found themselves, Marshall, in his attempts to find two physicians to reverse his initial certification by reexamining him, discovered that much of what he said and did was interpreted as evidence of his insanity. Charlotte MacKenzie (1985, 1992), in her study of the history of Ticehurst Asylum, makes the following point:

When Walter [Marshall] arrived at Ticehurst, the case notes suggest that his attendants had to search for signs of mental disturbance. They commented that: "His memory seems to be fair, he is quite coherent, and though he has not expressed any definite delusions, yet there seems to be working in him some idea of greatness... He is never idle, and within two days of admission had already painted several fairly executed pictures of the grounds, etc. (MacKenzie, 1985: 158).

In Marshall's case notes from Ticehurst, Hayes Newington (Samuel Newington's nephew and also a physician) commented: "Has confessed to having had a severe attack of syphilis 18 years ago. Has been put on iodide of potassium” (Vol. 22, 24 May, 1876). With hindsight, we can say that there was little reason to suppose that Marshall's states of excitement/depression were due to his suffering from general paralysis, the tertiary and terminal stage of syphilis. Marshall's wife, Annie, appears to have been free of the disease. Still, both Hays Newington and William Gull (who had also examined Marshall at Ticehurst), interpreted Marshall's tremulous tongue, and exalted state of mind as the first stage of general paralysis. In the case notes, even Marshall's paintings are viewed as being symptomatic: "His room ... is decorated with many of his own paintings and drawings, mostly of a gaudy, sensational, and jerky character. Some present the typical G.P. appearance -lots of colour grouped into purposeless masses” (Vol. 22, 18 August, 1876).

Despite Hayes Newington's professional judgment that Marshall suffered from the first signs of general paralysis, four months after he had been admitted to Ticehurst Asylum, Marshall was transferred to single care with a Dr. Hall in Brighton, was released a month later, and was well enough the following year to give evidence to Parliament's Select Committee on possible abuses of the lunacy laws.

\section{CONCLUSION}

Using the techniques of genre and discourse analysis, I have compared two sets of texts both relevant to the career of Walter Marshall as a psychiatric patient. I have also sought to cast the back story of Marshall's incarceration as a narrative, drawing on archival and secondary 
sources to construct the plausible story of the events leading to Marshall's confinement at Ticehurst and his testimony to Parliament's Select Committee on Lunacy Laws, a body investigating possible abuses of treatment of the mentally ill, or "lunatics" as they were called in the Victorian era, and earlier. What conclusions can be drawn from the unfortunate experience of Walter Marshall?

First of all, in nineteenth century England, confinement in an insane asylum, which is a profoundly physical act, can be seen to be the uptake (Austin, 1962) of discursive work of the two Medical Certificates, when filled out correctly -as they were by Drs. Seaton and James. These certificates, along with the Order for the Reception, and the Notice of Admission (a document that is filled out by the Asylum supervisor) must be filled out following certain strict procedures for the confinement to take place. In this respect the British Lunacy Laws provided protection for patients against wrongful confinement. In Marshall's case, all of the documents were correctly filled out, establishing the medico-legal grounds for his confinement.

Second, what are we to make of Marshall's testimony to Parliament's Select Committee? This patient's narrative of personal experience of confinement -his patient's tale, as it were- is, to the modern reader, a strong indictment of the weaknesses in the medico-legal system in the Victorian era, despite its protocols and its safeguards to protect the patient from illegal confinement.

I do not mean to suggest here that Marshall was not mentally ill. In fact, the details of his case notes while he was at Ticehurst Asylum between May and September, 1976, suggest that he was suffering from alternating episodes of mania and depression separated by lucid intervals. Unfortunately, it was not until 1899 that the psychiatrist, Emil Kraeplin, developed the illness classification of Manic-Depressive Illness as a mood disorder (distinguished from schizophrenia) that was to be diagnosed on the basis of the course of the illness over time. Thus, it was easy for Marshall's doctors to misread his symptoms, and misdiagnose his condition as Grand Paralysis, the tertiary and final stage of syphilis.

Third, did Marshall's testimony convince the members of the Select Committee to change the Lunacy Laws? The final report, which followed the transcribed Minutes of Evidence of 1877 Select Committee Hearings, acknowledges that there are several areas in asylum confinement that need to be more closely examined, but at the same time "finds no serious violations of the Lunacy Law or abuses occurring in the system, although the author admits that such infractions are -and remain a possibility" (Report of the Select Committee, 1877).

Although several other former asylum patients testified in 1877 about what they considered abuses of the Lunacy Laws, no new lunacy legislation was proposed by the Select Committee members. Nevertheless, the rhetorical power of the certificates, and their ability to result in a sane person's confinement did not escape the Victorian public's notice. To the contrary, novels such as Wilkie Collins’ Woman in White (1860) and Charles Reade’s Hard 
Cash (1863) depicted unscrupulous relatives paying large fees to physicians to interview and then to certify that a family member was of unsound mind. As it turned out, the fictional representation of wrongful confinement in Reade's and Collin's novels was to usher in an era of sensationalist novels in the 1860s. But that is for another study of narrative across fiction and non-fiction genres and beyond the scope of this essay.

\section{NOTES}

${ }^{1}$ An earlier, more elaborated version of the material in this section can be found in the first chapter of Patient Tales: Case Histories and the Uses of Narrative in Psychiatry University of South Carolina Press, 2008.

${ }^{2}$ For a more detailed analysis of Marshall's Admissions Records, of which the Medical Certificates are a part, see Berkenkotter \& Hanganu-Bresch, in press.

${ }^{3} \mathrm{Cf}$ an earlier, more truncated version of Marshall's biography as a person suffering from "nervous illness,” which appears in Berkenkotter \& Hanganu-Bresch, in press.

\section{REFERENCES}

Manuscript sources. Accession numbers beginning AR (admission record) and CB (casebook record) refer to records belonging to Ticehurst House Asylum and deposited in the Wellcome Institute for the History of Medicine, Western Manuscripts Collection, London.

Austin, J.L. (1962). How to Do Things with Words. Cambridge, MA: Harvard University Press.

Banks, J.T (1986). A controversy about clinical form. Literature and Medicine, 5, 24-26.

Barnard, D. (1986). A case of Amyotrophic Lateral Sclerosis. Literature and Medicine, 5, 27 42.

Barthes, R. (1977). Introduction to the structural analysis of narratives. Image-Music-Text. London, Fortuna

Berkenkotter, C. (2008). Patient Tales: Case Histories and the Uses of Narrative in Psychiatry. Columbia, SC: University of South Carolina Press.

Berkenkotter, C. \& Hanganu-Bresch, C. (in press). Occult genres and the certification of madness in a $19^{\text {th }}$ century lunatic asylum. Written Communication, 28(2).

Capps, L. \& Ochs, E. (1995). Constructing Panic: The Discourse of Agoraphobia. Cambridge, MA: Harvard University Press.

Charon, R. (1986). To render the lives of patients. Literature and Medicine, 5, 58-74.

Clifford, J. \& Marcus, G. (1986). Writing Culture: The Poetics and Politics of Ethnography. Berkeley: University of California Press.

Collins, W. (1860). The Woman in White. London: Sampson Low.

Coupland, N. \& Coupland, J. (1998). Reshaping lives: constitutive identity work in geriatric medical settings. TEXT, 18(2), 159-189.

Fakhri, A. (1998). Narration in journalistic and legal discourse. TEXT, 18(4), 445-465.

Freadman, A. (2002). Uptake. In R. Coe, L. Lingard, \& T. Teslenko (Eds.), The Rhetoric and Ideology of Genre: Strategies for Stability and Change (pp. 39-53). Creskill, NJ: Hampton Press.

Goodwin, C. (1984). Notes on story structure and the organization of participation. In J.M. Atkinson and J. Heritage (Eds.), Structures of Social Action (pp. 225-246). Cambridge: Cambridge University Press.

Hawkins, A.H. (1986). A.R. Luria and the art of clinical biography. Literature and Medicine, 5, 1-15.

Labov, W. (1972). The transformation of experience in narrative syntax. In Language in the Inner 
City: Studies in the Black English Vernacular (pp. 354-396). Philadelphia: University of Pennsylvania Press.

Labov, W. \& Waletzky, J. (1967). Narrative analysis: Oral Versions of Personal Experience. In June Helm (Ed.), Essays on the Verbal and Visual Arts (pp. 12-44). Seattle: University of Washington Press.

MacKenzie, C. (1985). Social factors in the admission, discharge, and continuing stay of patients at Ticehurst Asylum, 1845-1917 In W.F. Bynum, R. Porter \& M. Shepherd (Eds.), The Anatomy of Madness: Essays in the History of Psychiatry, Vol.2 (pp. 147-183). London: Tavistock Publications.

MacKenzie, C. (1992). Psychiatry for the Rich: A History of Ticehurst Private Asylum, 1792-1917. London: Routledge.

Merivale, H.C. (1879). My Experiences in a Lunatic Asylum by a Sane Patient. London: Chatto \& Windus.

Mishler, E.G. (1997). Narrative accounts in clinical and research interviews.In B.L. Gunnarsson, P. Linell, \& B. Nordberg (Eds.), The Construction of Professional Discourse (pp. 223-244). London: Longman.

Mitchell, W.J.T. (Ed). (1981). On Narrative. Chicago: University of Chicago Press.

Ochs, E., Smith, R., \& Taylor, C. (1989). Detective stories at dinnertime: Problem-solving through conarration. Cultural Dynamics, 2, 238-257.

Ochs, E., \& Capps, L. (2001). Living Narrative: Creating Lives in Everyday Storytelling. Cambridge, MA: Harvard University Press.

Perceval, J. (1840). A Narrative of the Treatment Experienced by a Gentleman During a State of Mental Derangement. London: Effingham Wilson.

Rabkin, E. (1986). A case of self-defense. Literature and Medicine, 5, 43-53.

Ravotas, D. \& Berkenkotter, C. (1998). Voices in the text: The uses of reported speech in a psychotherapist's notes and Initial Assessments. TEXT, 18(2), 211-239.

Reade, C. (1863, 1870). Hard Cash: A Matter of Fact Romance, $2^{\text {nd }}$ ed. Boston: De Wolfe, Fiske \& Co.

Report from the Select Committee on Lunacy Laws with Proceedings, Minutes of Evidence, and an Appendix. British Parliamentary Papers, 1877.

Rosenhan, D. C. (1973). Being sane in insane places. Science, 179, 179-185.

Routsong, T. R. (2010). Book Review of Patient Tales: Case Histories and the Uses of Narrative in Psychiatry. Rhetoric \& Public Affairs, 13 (3), 516-519.

Sacks, O. (1986). Clinical tales. Literature and Medicine, 5, 16-23.

Searle, J.R. (1979). Expression and Meaning: Studies in the Theory of Speech Acts. Cambridge: Cambridge University Press.

Smith, D.H. (1986). The limits of narrative. Literature and Medicine, 5, 54-57.

Todorov, T. (1990). Genres in Discourse (C. Porter, Trans.). Cambridge: Cambridge University Press.

Van Eemeren, F.H. \& Grootendorst, R. (1983). Speech Acts in Argumentative Discussions. Dordrecht, Netherlands: Foris.

White, H. (1987). The Content of the Form: Narrative Discourse and Historical Representation. Baltimore: Johns Hopkins University Press. 